\title{
Neoliberal Thinkers and European Integration in the 1980s and the Early 1990s
}

\author{
Roberto Ventresca (ic) \\ Department of Political Science, Law and International Studies, University of Padova, Via del Santo, 28-35123 Padova, Italy \\ roberto.ventresca@unipd.it/roberto.ventresca87@gmail.com
}

This article explores how a specific strand of neoliberal-oriented intellectuals, namely those who revolved around the Mont Pèlerin Society (MPS), conceptualised the EEC policies between the 1980s and the early 1990s. In particular, this contribution considers two MPS general meetings, respectively held in 1982 and 1990, which were dedicated to the issue of European integration. Drawing on both primary and secondary sources, this article first assesses how neoliberal thinkers commented on and interpreted the EEC transformations during the 1980s. Second, it challenges the assumption according to which the run-up to the establishment of the EU was the outcome of a consolidated project of neoliberalisation of the EEC and EU institutions. Finally, this article shows in which terms these neoliberal thinkers conceived of the depoliticisation of European institutions after the fall of the Berlin Wall and the looming end of the Cold War.

\section{Introduction: Neoliberals and European Integration after the 'Shock of the Global'}

About thirty years after the fall of the Berlin Wall, many scholars have explored how the outbreak of the 'global 1989'1 led Europe to lose its role as the direct and indirect epicentre of the bipolar confrontation, ${ }^{2}$ while the dismantlement of the 'Cold War game' intertwined with the reconfiguration of the pillars upon which the process of European integration had been built since the end of the Second World War. When the twelve member states of the European Economic Community (EEC) signed the Maastricht Treaty on 7 February 1992 and gave birth to the European Union (EU), the very ingredients of the European Cold War scenario seemed to be suddenly replaced by the unipolar triumph of Western narratives $^{3}$ - to wit, the no longer disputable hegemony of liberal political systems combined with market-oriented economic settlements. Yet, historians have highlighted how the changes that interlaced the process of European integration with the shift from the so-called Keynesian consensus to a somehow unprecedented shape of capitalism - that is, the neoliberal paradigm ${ }^{4}-$ unfolded in a quite non-linear way. ${ }^{5}$ This article explores how this pivotal turn in European history was

1 Frédéric Bozo, Marie-Pierre Rey, N. Piers Ludlow and Leopoldo Nuti, eds., Visions of the End of the Cold War in Europe, 1945-1990 (New York: Berghahn Books, 2012); Jacques Rupnik, ed., 1989 as a Political World Event: Democracy, Europe, and the New International System in the Age of Globalization (London: Routledge, 2015); Paul Betts, '1989 at Thirty: A Recast Legacy', Past and Present, 244, 1 (2019), 271-305.

2 Federico Romero, Storia della guerra fredda. L'ultimo conflitto per l'Europa (Torino: Einaudi, 2009), 10-11.

3 Michael Cox, 'Another Transatlantic Split? American and European Narratives and the End of the Cold War', Cold War History, 7, 1 (2007), 121-46.

4 David Harvey, A Brief History of Neoliberalism (New York: Oxford University Press, 2005); Barbara Stiegler, 'Il faut s'adapter'. Sur un nouvel impératif politique (Paris: Gallimard, 2019); William Callison and Zachary Manfredi, eds., Mutant Neoliberalism: Market Rule and Political Rupture (New York: Fordham University Press, 2020); Iain Stewart, 'On Recent Developments in the New Historiography of (Neo)Liberalism', Contemporary European History, 29, 1 (2020), 116-24.

5 Aurélie Andry, Emmanuel Mourlon-Druol, Haakon Ikonomou and Quentin Jouan, 'Rethinking European Integration History in Light of Capitalism: The Case of the Long 1970s', European Review of History, 26, 4 (2019), 553-72.

(C) The Author(s), 2021. Published by Cambridge University Press. This is an Open Access article, distributed under the terms of the Creative Commons Attribution licence (http://creativecommons.org/licenses/by/4.0/), which permits unrestricted re-use, distribution, and reproduction in any medium, provided the original work is properly cited. 
conceptualised by a specific strand of neoliberal-oriented intellectuals, namely those who revolved around the Mont Pèlerin Society (MPS) ${ }^{6}$ during the 1980s.

Anything but a monolithic body of thought, neoliberalism has historically germinated along several intellectual and political strands, whose manifold shapes include, first, the Austro-Americans (i.e. F.A. von Hayek, L. von Mises) and their conceptualisation of the market economy as the outcome of unplanned interactions among actors provided with limited knowledge and, at the same time, encased within binding but endlessly adaptive market rules. Second, the ordoliberals from the Freiburg School (i.e. W. Eucken and F. Böhm, then linked to the 'sociological' branch of W. Röpke, A. Müller-Armack and A. Rüstow), who advocated the setting up of strong institutional and legal frameworks aimed at preserving the smooth functioning of the market economy without any external - that is, political interference. ${ }^{7}$ Third, the Chicago School (i.e. M. Friedman, A. Director), whose hostility towards any public authorities' efforts to interfere with the principle of free competition in the realm of economic and monetary relations went hand in hand with the staunch preservation of individual liberty and property rights. Finally, the Virginia (i.e. J. Buchanan and his 'public choice' theory) ${ }^{8}$ and the Geneva schools of thought (embodied by people who mainly worked at the General Agreement on Tariffs and Trade, GATT, such as J. Tumlir or E.U. Petersmann), ${ }^{9}$ which pivoted, respectively, around the need for 'constitutional constraints' against the action of self-interested national governments and the designing of supranational institutions committed to the global implementation of the ordoliberal 'economic constitution' through the removal of barriers to free trade and capital circulations. ${ }^{10}$

Notwithstanding such diversities in the historical making of neoliberalism, I interpret it as a collective - though conflicting - school of thought, whose primary goal consists in shaping both social and individual lives according to the precept of competition, the primacy of market over social-oriented policy goals, the depoliticisation of economic relations and the use of price mechanisms as the most legitimate signals through which to 'adjust' the institutional and political set of rules upon which capitalist societies must be built. Therefore, neoliberalism's adaptability to changing politico-institutional frameworks, variable intellectual climates of opinion, as well as external economic shocks, is one of the most distinguishing, but often overlooked, attributes of the neoliberal school of thought. ${ }^{11}$ Far from being an 'agentless spirit of capitalism', ${ }^{12}$ the neoliberal thought collective unfolded through the operational engines of transnational networks of research centres and think tanks, ${ }^{13}$ which were committed to the transformation of neoliberals' intellectual claims into global policy prescriptions. This is the reason why it is of particular interest to take into consideration the MPS - which embodied (and still embodies) one of the largest and most effective transnational hubs of neoliberal supporters since 1947 - as a fruitful historiographic perspective through which to tackle both the neoliberal movement's plural perceptions and prescriptions concerning EEC policies during the 'long' 1980s. Although the MPS cannot be considered as an omni-comprehensive collector of all the aforementioned strands of the neoliberal community, the insights that one can draw from the scrutiny of its sources are representative of the main trends, contradictions, and potential counternarratives that marked the interpretations of European integration by the leading figures of transnational neoliberalism at that time.

${ }^{6}$ Dieter Plehwe and Philip Mirowski, eds., The Road from Mont Pèlerin: The Making of the Neoliberal Thought Collective (Cambridge, MA: Harvard University Press, 2009).

7 Werner Bonefeld, The Strong State and the Free Economy (London: Rowman \& Littlefield, 2017).

8 Daniel Stedman Jones, Masters of the Universe: Hayek, Friedman and the Birth of Neoliberal Politics (Princeton: Princeton University Press, 2012), 68.

9 Quinn Slobodian, Globalists: The End of Empire and the Birth of Neoliberalism (Cambridge, MA: Harvard University Press, 2018).

10 William Callison and Zachary Manfredi, 'Theorizing Mutant Neoliberalism', in Callison and Manfredi, Mutant, 7.

11 Quinn Slobodian and Dieter Plehwe, 'Introduction', in Dieter Plehwe, Quinn Slobodian and Philip Mirowski, eds., Nine Lives of Neoliberalism (London: Verso, 2020), 6.

12 Slobodian and Plehwe, 'Introduction', 3.

13 Marie Laure Djelic and Reza Mousavi, 'How the Neoliberal Think Tank Went Global: The Atlas Network, 1981 to the Present', in Plehwe, Slobodian and Mirowski, Nine Lives, 258. 
The interest in a historical investigation of the MPS neoliberals' attitude towards the EEC also lies in the acknowledgement of the diverging reactions that the Community's role in the international economic relations spurred among transnational neoliberal circles since the Treaty of Rome's signing in 1957. As noticed by Quinn Slobodian, the envisaging of a European pattern of 'multilevel governance $^{14}$ (that is, a system of trade barriers against external countries and preferential tariffs for EEC-associated nations, including the former colonies of several EEC member states) was perceived by the intellectuals linked to the Austro-American and the Geneva neoliberal schools as a threat to the already existing 'universalist' frameworks for the management of global trade and economic relations, such as the one embodied by the GATT. Therefore, the investigation into how the MPS neoliberals dealt with European integration in the 1980s allows us to assess how the relationship between the transnational neoliberal community and European integration evolved after the crucial turning point of the economic, social and monetary crises of the 1970s that embodied the so-called 'shock of the global'. ${ }^{15}$

Consequently, this article pursues three interrelated objectives. First, it demonstrates that the analysis of how the MPS conceptualised European integration after the collapse of the Bretton Woods system (1971), the two oil shocks (1973 and 1979), ${ }^{16}$ the elections of Thatcher in the United Kingdom and Reagan in the United States (1979-80) and the EEC counter-responses to the monetary turmoil of the 1970 s - i.e. the setting up of the European Monetary System (EMS) in 1978-9 $9^{17}$ - is crucial to understanding whether the transnational neoliberal community perceived the process of European integration as a source of political and intellectual contention during the 'heyday' of globalisation ${ }^{18}$ and the alleged triumph of neoliberal market-oriented narratives.

In so doing, this study rethinks, second, the history of European integration as a revealing mirror of the trajectories through which the transnational neoliberal community reflected upon its own features and tenets during the 1980s. The occasion for MPS-linked theorists (i.e. Milton Friedman, James Buchanan, Victoria Curzon Price, or Jagdish Bhagwati) to discuss their views was provided by two MPS general meetings, respectively held in Berlin in September 1982 and in Munich in September 1990. While the MPS's interest in European integration stemmed from its very first meeting in 1947 - when the participants debated about 'the problem and chances of European Federation' ${ }^{19}$ - the gatherings of 1982 and 1990 have been chosen since they happened in conjunction with two crucial turning points for both the EEC and the broader system of international relations after the Second World War. The Berlin meeting was convened when the first effects of the EMS's counter-response to the monetary turmoil of the 1970s appeared and the EEC countries were striving to deal with the instability of the dollar and the spread of US international 'Reaganomics'. ${ }^{20}$ The Munich meeting in 1990 occurred in parallel to two momentous and global events: the looming disintegration of the Soviet system after the fall of the Berlin Wall, ${ }^{21}$ as well as the forthcoming negotiations for the Maastricht Treaty and the 'road' to the European

\footnotetext{
14 Slobodian, Globalists, 204-205.

15 Niall Ferguson, Charles S. Maier, Erez Manela and Daniel J. Sargent, eds., The Shock of the Global: The 1970s in Perspective (Cambridge, MA: Harvard University Press, 2010).

16 Giuliano Garavini, Duccio Basosi and Massimiliano Trentin, eds., Counter-Shock: The Oil Counter-Revolution of the 1980s (London: Bloomsbury Academic, 2018).

17 Emmanuel Mourlon-Druol, A Europe Made of Money: The Emergence of the European Monetary System (Ithaca: Cornell University Press, 2013).

18 Laurent Warlouzet, Governing Europe in a Globalizing World: Neoliberalism and Its Alternatives After the 1973 Oil Crisis (London: Routledge, 2018), 1; Paolo Capuzzo, 'Markets', in Martin Conway, Pieter Lagrou and Henry Rousso, eds., Europe's Postwar Periods - 1989, 1945, 1918. Writing History Backwards (London: Bloomsbury Academic, 2019 ), 157.

19 Slobodian, Globalists, 184.

20 Duccio Basosi, 'The European Community and International Reaganomics, 1981-1985', in Kiran Patel and Kenneth Weisbrode, eds., European Integration and the Atlantic Community in the 1980s (New York: Cambridge University Press, 2013), 133-53.

21 Vladislav Zubok, A Failed Empire: The Soviet Union in the Cold War from Stalin to Gorbachev (Chapel Hill: University of North Carolina Press, 2007).
} 
Monetary Union (EMU). ${ }^{22}$ Therefore, the analysis of the Munich meeting's sources is crucial to grasp under which terms the MPS affiliates endorsed the achievements of European integration in the 1980s as 'familiar' outcomes of their own long-lasting intellectual and political commitment, thus helping us to better define what kind of 'integration' the EEC policy makers had promoted in the broader context of the 1980s' Cold War scenario. In light of the decay of neoliberalism's historical enemies - collectivism, planning and communism - the scrutiny of the 1990 MPS meeting is fundamental to explore the extent to which MPS neoliberals considered the EEC as a helpful institutional platform to enhance the international grip of free-market prescriptions after the seeming demise of the Soviet bloc.

Third, this study challenges the assumptions ${ }^{23}$ according to which the run-up to the establishment of the EU in 1992 might be considered as the outcome of a project of neoliberalisation of Western European institutions under the direct or indirect pressure of Reagan's policies in the United States, Thatcher's experience in the United Kingdom and the global spread of the so-called 'Washington consensus'. ${ }^{24}$ Rather, this article further demonstrates how the reconfiguration of the EEC during the 'age of Reagan ${ }^{25}$ was anything but a teleological path towards the adoption of pure market-oriented policy prescriptions. If the Maastricht Treaty is largely seen as a pivotal systematisation of the long-term 'encasement ${ }^{26}$ of pro-market rules in the operational mechanisms of the former EEC area, the coexistence of plural economic cultures among European policy makers, parties and institutions in the 1970s-80s (namely, social, neo-mercantilist and market-oriented policies) ${ }^{27}$ reveals how the transformation that took shape in the EEC during the 1980s resulted from a harsh conflict between diverging policy options and alternative political traditions. Consequently, a fundamental historiographic question arises: to what extent did neoliberals themselves look at the 1980s' European integration as the mirror of their own political and intellectual triumph?

After providing a short overview of Western Europe's political landscape in the early 1980s, in the first section I explain how neoliberal intellectuals - such as Milton Friedman, Victoria Curzon Price and Robert Lozada-Heller - interpreted the EEC's reactions to the global transformations of the 1970s during the 1982 MPS general meeting in Berlin. While Friedman and Curzon Price's positions mainly focused on the EEC trade policies and the alleged regulative stance embodied by European institutions, Lozada-Heller's contribution explored the 'exceptional' experience of Mitterrand's France and its growing strains in coping with the ever-binding EEC's economic and monetary rules in the early 1980 s. $^{28}$

In the second part, I consider MPS approaches to European integration in the late 1980s and I pay attention to the 1990 MPS general meeting held in Munich, which was entirely dedicated to the topic of 'Europe in an Open World Order'. Just after the fall of the Berlin Wall and the looming implosion of the Soviet system, the speeches delivered by Gerard Radnitzky, Jürgen von Hagen, Michele

\footnotetext{
22 Kennet Dyson and Kevin Featherstone, The Road to Maastricht: Negotiating Economic and Monetary Union (Oxford: Oxford University Press, 1999).

23 François Denord and Antoine Schwartz, L'Europe sociale n'aura pas lieu (Paris: Raisons d'Agir, 2009); John Gillingham, European Integration 1950-2003: Superstate or New Market Economy? (Cambridge: Cambridge University Press, 2003). Others have claimed that 'Those who say that the European Union is a neoliberal plot are, of course, largely right'. See Simon Nixon, 'The European Union's Neoliberal Dilemma', The Wall Street Journal, 4 Oct. 2017, quoted in Quinn Slobodian and Dieter Plehwe, 'Neoliberals Against Europe', in Callison and Manfredi, Mutant, 89-90.

24 John Williamson, ed., The Political Economy of Policy Reform (Washington, DC: Institute for International Economics, 1994).

25 Sean Wilentz, The Age of Reagan: A History: 1974-2008 (New York: Harper, 2008).

26 'What neoliberalism sought over the decades was an institutional encasement for the world of nations that would prevent catastrophic breaches of the boundaries between imperium [the world conceived as a set of territorial states] and dominium [the world of property]'. Slobodian, Globalists, 13.

27 Laurent Warlouzet, 'The European Commission Facing Crisis: Social, Neo-mercantilist and Market-Oriented Approaches (1967-85)', European Review of History, 26, 4 (2019), 553-72.

28 Jean-Gabriel Bliek and Alain Parguez, 'Mitterrand's Turn to Conservative Economics: A Revisionist History', Challenge, 51, 2 (2009), 97-109.
} 
Fratianni, Jagdish Bhagwati, Karl-Heinz Paqué and James Buchanan framed the ongoing debates about the so-called 'Europe 1992' initiative ${ }^{29}$ within the overarching context of a critical recount of the EEC monetary, social and even constitutional dimensions. While communism seemed to have been wiped out under the ruins of the Berlin Wall, regulatory practices still nourished neoliberals' scepticisms about the so-called European construction.

\section{Monitoring the European Community in the Early $1980 \mathrm{~s}$}

After a decade marked by the combination of deep economic stagnation and harsh social conflicts across the largest capitalist countries (such as France, Italy, the United Kingdom, West Germany and the United States), between 1978 and 1981 significant political transformations occurred in the Western world. ${ }^{30}$ While the neoliberal turn gained momentum with the election of Margaret Thatcher in the United Kingdom in $1979^{31}$ and Ronald Reagan's electoral victory in the 1980 US presidential elections, the largest countries of continental Europe were dealing with a different scenario.

In the 1981 French presidential elections, the leftist coalition led by Mitterrand's Socialist Party prevailed against the conservative Giscard D'Estaing. However, in March 1983 the French government launched its well-known tournant de la rigueur, which somehow represented a market-oriented U-turn in the management of France's economic policy. ${ }^{32}$ As for West Germany, since 1974 Helmut Schmidt had been leading a governmental alliance between the Social Democrats and the Liberal Party that would subsequently be replaced by Kohl's right-wing cabinet in October $1982 .{ }^{33}$ Finally, after the dismissal of the 'historic compromise' strategy between the Christian Democrats (DC) and the Italian Communist Party, ${ }^{34}$ since the early 1980s Italy had experienced the formula of the centre-left pentapartito (five-party system), and the prospect of including communist representatives in Italy's governmental alliance rapidly faded away. ${ }^{35}$

Anything but a passive subject of the global economic context, the EEC aimed at building up its own reaction to the challenges of the 1970s: inflation peaks, slow growth rates, unemployment and the instability of the dollar. In particular, this resulted in the promotion of both monetary - namely, the creation of the EMS in 1979, which partially echoed previous projects of European monetary integration, such as the Werner Plan ${ }^{36}$ - and political measures, such as the reinforcement of the by then limited political prerogatives of the European parliaments over the treaties signed by the community. ${ }^{37}$ This process first started under the Jenkins presidency in $1976^{38}$ and then gained momentum when Jacques Delors was appointed president of the commission in 1985. Thanks to the Single European Act of 1986-7, which scheduled the full liberalisation of goods, services, people and capitals within

\footnotetext{
29 Mark Gilbert, Surpassing Realism: The Politics of European Integration since 1945 (London: Rowman \& Littlefield, 2003), 175.

30 Gerd Rainer Horn, The Spirit of '68: Rebellion in Western Europe and North America, 1956-1976 (Oxford: Oxford University Press, 2007).

31 Benjamin Jackson and Robert Saunders, eds., Making Thatcher's Britain (Cambridge: Cambridge University Press, 2012).

32 Michel Maurice Loriaux, France after Hegemony: International Change and Financial Reform (Ithaca: Cornell University Press, 1991); Frédéric Bozo, Mitterrand, la fin de la guerre froide et l'unification allemande. De Yalta à Maastricht (Paris: Odile Jacob, 2005).

33 Hartmut Soell, Helmut Schmidt. 2. 1969 bis Heute. Macht und Verantwortung (Munich: Deutsche Verlags-Anstalt, 2008).

34 Silvio Pons, The Global Revolution: A History of International Communism (Oxford: Oxford University Press, 2014), 285-91.

35 Antonio Varsori, Italy's Foreign Policy in the 1980s: From Enthusiasm to Disillusion, in Antonio Varsori and Benedetto Zaccaria, eds., Italy in the International System from Détente to the End of the Cold War: The Underrated Ally (Cham: Palgrave Macmillan, 2018), 104.

36 Elena Danescu, 'Pierre Werner: A Visionary European and Consensus Builder', in Kenneth Dyson and Ivo Maes, eds., Architects of the Euro: Intellectuals in the Making of European Monetary Union (Oxford: Oxford University Press, 2016), 93-116.

37 Gilbert, Surpassing, 176.

38 Piers Ludlow, Roy Jenkins and the European Commission Presidency: At the Heart of Europe, 1976-1980 (London: Palgrave Macmillan, 2016).
} 
the Single Market by 1992, Delors contributed to the reconfiguration of EEC institutions in the context of a rising market-led globalisation. ${ }^{39}$ In this respect, while the neoliberal and conservative-oriented move in the United States had already 'altered the terms of the debate ${ }^{40}$ of the transatlantic relations, Delors's relaunch of European integration was progressively put under scrutiny by neoliberals and, namely, by the MPS.

In the early 1980s, the MPS was considered one of the most credited and global hubs of neoliberal advocates. Founded in April 1947 at Mont Pèlerin, close to Geneva, thanks to the efforts of Albert Hunold and Friedrich von Hayek (and the funding of two US institutions), ${ }^{41}$ the MPS developed into a prominent, though elusive, neoliberal-oriented transnational network, whose primary goal was that of infusing free market culture within political institutions, corporate bodies, media and universities. According to Hayek, the MPS has always acted only to 'provide for its members an opportunity to clear their own minds in problems they haven't themselves intensively studied'. ${ }^{42}$ Beyond Hayek's self-celebrating claims, the MPS pioneered the establishment of further likeminded organisations across the world, namely the 'dense network' ${ }^{43}$ of neoliberal think tanks (e.g. Heritage Foundation, Cato Institute, Institute of Economic Affairs) which exerted a remarkable - though often indirect $^{44}$ - influence, especially on US and Western European politics. Although the majority of the MPS affiliates ${ }^{45}$ since its foundational years have come from North America, Europe remained an equal epicentre of the neoliberal intellectual community. Contrary to the common conviction that neoliberalism is an ideology 'made in [the] USA, [until 2009] fifteen of twenty-four MPS presidents have been Europeans, and six have come from the United States'. ${ }^{46}$

In 1980-1, 'Reaganomics' suddenly ignited new tensions between the US and their EEC partners, who harshly criticised Washington's policies of high interest rates, which were deemed to provoke an increasing outflow of capital from Western Europe into the US markets. ${ }^{47}$ These policies implied the strengthening of the dollar against European currencies, whose trends were then managed within the fluctuation bands indicated by the EMS agreements. This combination of the United States's audacious anti-inflationary commitment and the lingering effects of the second oil shock left Western Europe - Thatcher's United Kingdom included ${ }^{48}$ - in an uneasy position. The unilateralism of Reagan's move had a powerful impact on EEC economies and, quite unsurprisingly, the members of the transnational neoliberal community concentrated their attention on Western Europe's stance within what appeared to be a propitious conjuncture for the further spread of free market ideas and policy prescriptions.

An opportunity was offered by the MPS general meeting held in Berlin in September 1982, titled 'For a Free Society in the Coming Decade'. The panel dedicated to Europe - 'The European Economic Community: Friend or Foe of the Market Economy? ${ }^{49}$ - was opened by a short contribution from the 1976

\footnotetext{
39 Alessandra Bitumi, “An Uplifting Tale of Europe”: Jacques Delors and the Contradictory Quest for a European Social Model in the Age of Reagan', Journal of Transatlantic Studies, 16, 3 (2018), 207.

40 Bitumi, 'An Uplifting', 205.

41 The Foundation for Economic Education in New York and the William Volker Fund in Kansas City. See Dieter Plehwe, 'Introduction', in Plehwe and Mirowski, The Road, 15.

42 'Economics, Politics, \& Freedom: An Interview with FA Hayek', Reason, February 1975, 6.

43 Djelic and Mousavi, 'How the Neoliberal', 258.

44 By stressing the non-partisan tone of their activities, neoliberal organisations try to catch media and policy makers' attention and to present themselves as reliable actors in the public sphere. See Richard Cockett, Thinking the Unthinkable: Think-Tanks and the Economic Counter-Revolution, 1931-1983 (London: Harper Collins, 1994).

45 The list of the by-then MPS members is available in the MPS archives held by the Hoover Institution Library \& Archives in Stanford, CA, United States.

46 Plehwe, 'Introduction', in Plehwe and Mirowski, The Road, 15.

47 Basosi, 'The European Community', 142-3.

48 Ibid., 144.

49 Milton Friedman, 'The European Community: Friend or Foe of the Market Economy?', The Mont Pèlerin Society General Meeting - 5th-10th September 1982, Berlin, Milton Friedman papers [hereafter: MF], box 112, Hoover Institution Library \& Archives [hereafter: HILA]. Hereafter: Friedman, 'The European'.
} 
Nobel prize winner in economics, ${ }^{50}$ Milton Friedman. In this speech, Friedman recalled his first experience in Western Europe, when in 1950 he travelled to Paris to serve as a consultant for the Economic Cooperation Administration (ECA) in the framework of the Marshall Plan $^{51}$ and the early debates on European integration. While he clarified that he could not be considered an expert on European politics and economics, Friedman recounted the main conclusions of his 1950 report to the ECA.

First, if European countries eventually set up a common market of goods and services, they should also create a system of flexible exchange rates among their currencies. In Friedman's opinion, such a need would have been demonstrated by the subsequent and continuous adjustments settled by the EEC authorities in the context of the European Payments Union (EPU), ${ }^{52}$ the early 1970 s 'snake, ${ }^{53}$ and the EMS, which - contrary to Friedman's theoretical convictions - did not envisage a system of purely floating rates but rather established a zone of relatively stable exchange rates among EEC currencies. ${ }^{54}$ Second, the US administration should have only promoted the reduction of trade barriers on a multilateral basis, rather than the establishment of a continental common market, in the belief that 'free trade worldwide' would be better 'than within the European community alone'. ${ }^{55}$ Friedman's criticism of the EEC's regional shape - which led the Community to become a propeller of international 'trade distortions', as he maintained, according to Jacob Viner's claims ${ }^{56}$ - clearly emerged in this address. Friedman tended to marginalise, though not entirely deny, the contribution of the EEC to the growth of international trade after 1945, whose performances, in his opinion, were not comparable to those of Far East countries or other non-European states, such as the OPEC countries. Not only did he believe that the spill-over process - from economic integration to progressive political unification - implicitly envisaged by the European functionalists had 'little historical evidence', but he also maintained that the overall design of European integration hurt the very interests of its member states, so that he tended to answer the basic question of his paper - whether the EEC could be considered as 'a friend or foe of the market economy' - in a quite assertive way: given the relatively low impact that Western Europe had on the overall growth of post-1945 international trade, the European common market 'was more likely to be [considered as] a foe than a friend of free markets. ${ }^{57}$

Friedman's criticisms of the EEC trade and monetary policies must be framed within his fight for the setting up of an international floating exchange rate system, against Hayek, von Mises and Röpke's call for the restoration of the gold standard rule after the end of the Second World War. ${ }^{58}$

50 On the controversy of the Nobel prize in economics see Philip Mirowski, 'The Neoliberal Ersatz Nobel Prize', in Plehwe, Slobodian and Mirowski, Nine Lives, 219-54.

51 Alan S. Milward, The Reconstruction of Western Europe, 1945-1951 (London: Methuen, 1984).

52 Jacob J. Kaplan and Günter Schleiminger, The European Payments Union: Financial Diplomacy in the 1950s (Oxford: Clarendon Press, 1989).

53 The 'snake' was a monetary agreement established in March-April 1972 by the EEC countries, with the participation of Great Britain, Ireland and Denmark. It aimed at setting up a system of pre-fixed exchange rate fluctuations between, on the one hand, European currencies and, on the other, between them and the dollar. The 'snake' was adopted mainly as a consequence of the Nixon administration's decision to suspend the dollar convertibility into gold in August 1971 and the ensuing Smithsonian Agreements of December 1971, which had set the European currencies' margin of fluctuation within a band oscillating between $\pm 1 \%$ and $2.25 \%$ against the central rate of the dollar and $\pm 4.45 \%$ among them. This band was then considered too large by some of the EEC's hard currencies countries, such as Germany and the Netherlands, which in March-April 1972 managed to create narrower bands of fluctuation $( \pm 1-1.125 \%$ against the dollar rate and $\pm 2.25 \%$ among European currencies), that is, the 'snake in the tunnel'. The 'snake' proved to be unsuccessful in 1973, especially after the further devaluation of the dollar (10\%), European currencies' instability, as well as the first oil shock. However, many of its features would be then retrieved by the European Monetary System in 1978. See Francesca Fauri, L'Italia e l'integrazione economica europea, 1947-2000 (Bologna: Il Mulino, 2000), 153-155.

54 Warlouzet, Governing Europe, 146; Mourlon-Druol, A Europe.

55 Friedman, 'The European'.

56 Friedman often refers to Jacob Viner, The Customs Union Issue (New York: Carnegie Endowment for International Peace, 1950).

57 Friedman, 'The European'.

58 Matthias Schmelzer, 'What Comes After Bretton Woods? Neoliberals Debate and Fight for a Future Monetary Order', in Plehwe, Slobodian and Mirowski, Nine Lives, 196-7. 
Notwithstanding the predominance of Friedman's positions in the US reconfiguration of the post-Bretton Woods international monetary order, ${ }^{59}$ the EMS clearly embodied a sort of exception, which highlighted the European (in particular, the Franco-German) belief in the positive impact that monetary stability, rather than free floating currencies, could have on EEC countries' growth and trade - let alone monetary - performances. ${ }^{60}$ In this respect, the prevailing ordoliberal Bundesbank's quest for stability-oriented policies moulded the EEC response to the challenges of global monetary turmoil and marked the defeat of Friedman's views within the intellectual confrontation with his ordoliberal counter-partners based in Western Europe: thus, Friedman's dissatisfaction with the EEC in the early 1980s was all but unexpected.

These views were in many respects shared by Victoria Curzon Price, professor at the Institut d'études européennes in Geneva and then president of the MPS in 2004-6. ${ }^{61}$ As an expert on international economics, she supported Friedman's claims concerning the distortive effects of the EEC's external trade policies. Moreover, she explored the twisted relationship between the EEC social and economic harmonisation policies and Brussels's contribution to the implementation of a fully-fledged global market economy. Building on Röpke's fear that the adoption of the principle of European 'harmonisation' would lead Germany - and by extension Western Europe - into the 'vortex of indicative planning on a grand scale, ${ }^{62}$ Curzon Price blamed the EEC's adoption of social criteria in the implementation of the broader community's trade strategies. In her opinion, the Treaty of Rome was premised on the wrong assumption that 'free trade cannot be fair trade unless all starting positions are equalised', instead of assuming that 'the equalisation of prices of goods and factors is the end product of trade, not its starting point'. ${ }^{63}$

Curzon Price's reproach of the EEC's social policies hinged on the 1978-83 extension of Brussels's social agenda to workers' health and security, gender equality and the environment, including the use of the European Regional Development Fund (1972-5) ${ }^{64}$ to help the poorest regions of the community (e.g. the Italian Mezzogiorno) and redistribute wealth as a source of social cohesion among EEC countries. ${ }^{65}$ She also maintained that the early 1980s' 'EEC Industrial Strategy' - namely, the EEC programme to boost coordinated industrial growth beyond the 'traditional' coal and steel sectors ${ }^{66}$ would trigger an excessive concentration of EEC enterprises, thus contradicting Article 92 of the Treaty of Rome, which prohibited state aid to national firms, as well as a harmful expansion of the European Commission's bureaucratic tasks. ${ }^{67}$

Curzon Price's crusade against the attribution of social purposes to the commission also alluded to both the debates on the 1980 'Vredeling Directive', which envisaged the reinforcement of workers' representatives in multinationals and the reduction of working time, ${ }^{68}$ and the more general 'Social Europe' agenda, which conveyed (with limited achievements indeed) European Social Democrats' call for the redistribution of wealth and the protection of labour's rights. ${ }^{69}$ Hence, Curzon Price's rebuttal to the overall EEC economic and social strategies seemed to evoke Wilhelm Röpke and

59 Schmelzer, 'What Comes', 216-8.

60 Warlouzet, Governing Europe, 146.

61 To date, she is the only woman ever appointed president of the MPS.

62 Victoria Curzon Price, 'The European Community: Friend or Foe of the Market Economy?', MF, box 12, HILA. Hereafter: Curzon Price, 'The European'.

63 Curzon Price, 'The European'.

64 Antonio Bonatesta, 'La politica regionale comunitaria nell' “età del disordine”. Dallo "sviluppo armonioso" alle ragioni del mercato (1972-1987),' Italia Contemporanea, n. 292 (2020), 213-41.

65 Warlouzet, Governing Europe, 39-41.

66 Arthe Van Laer, 'The European Community and the Paradoxes of U.S. Economic Diplomacy: The Case of the IT and Telecommunications Sectors', in Patel and Weisbrode, European Integration, 106.

67 Curzon Price, 'The European'.

68 The Dutch Labour Party's member, Henk Vredeling, became Commissioner of Social Affairs in 1977 and his 1980 Directive aimed at fostering the (eventually failing) agenda of 'Social Europe'. See Laurent Warlouzet, 'The European Commission', 711.

69 Aurélie Andry, 'Social Europe in the Long 1970s. The Story of a Defeat', PhD Thesis, European University Institute, 2017. 
Fritz Machlup's reflections on the side effects of a misinterpreted 'integration' of the European economy. If the very concept of economic integration generally refers, according to Machlup, 'to the division of labour. . . the mobility of goods or factors or both; and. . . to the discrimination or non-discrimination in the treatment of goods and factors, ${ }^{70}$ it could also imply severe distortions in the economic realm, should this integration include only 'some markets - say, for certain agricultural and industrial products, or for certain kinds of labour - [and not] all markets'. ${ }^{71}$ In his opinion, only general economic integration - based on the interdependence of all means of production calculated according to the principle of opportunity cost - prevents market distortions and the hampering of trade and capital circulation among countries or regional blocs.

Curzon Price's crusade against the redistributive implication of the EEC's social policy and harmonisation agenda encapsulated neoliberals' rejection of the EEC disintegrative policies, ${ }^{72}$ namely, sectorial or 'distorted' integration (from the 'European Industrial Strategy' to the Vredeling Directive) that could negatively affect the European economy as a whole. In this respect, European economic rules were not criticised per se, but only in so far as they were propelled to pursue the goals of greater social harmonisation. Not by chance, in 1985 Herbert Giersch (president of the MPS between 1986 and 1988), would devote his famous paper titled 'Eurosclerosis" ${ }^{\text {,73 }}$ to the issue of the EEC labour market 'rigidity'. The structure of workers' wages and the centralisation of wage bargaining - if linked to Western Europe's low productivity rates and a lack of technological innovation were bound to worsen the imbalances that, in Giersch's opinion, affected the EEC area when compared with the vitality of either the United States or East Asian countries. Rigidities in the European labour market were thereby conceptualised within the broader framework of 'syndicalism and guild socialism [that] Europe has developed to protect former scarcity rents and to preserve established positions' ${ }^{74}$

Symptomatically, the 'sclerosis' of the EEC's performances was interpreted by prominent MPS representatives as the consequence of the 'distortive' effect brought about by socialist and Social Democratic political forces' role in the management of industrial relations at both the national and the EEC levels. This is likely the reason why, notwithstanding the general failure of the 'Social Europe' agenda, MPS neoliberals staunchly opposed the adoption of an all-encompassing and binding social policy at the EEC level until the signing of the Maastricht Treaty in $1992 .^{75}$

Between the late 1970s and the early 1980s, the issue of how to combine the strengthening of social rights, the bridling of inflation rates and the relaunch of economic growth primarily involved leftist-oriented organisations at both the EEC and the national levels. In May 1981 the French presidential elections gave birth to a governmental alliance between the socialist and the communist parties under the presidency of François Mitterrand, who promoted a programme of economic reflation which pivoted on the improvement of domestic demand, the nationalisation of key companies and

\footnotetext{
70 Fritz Machlup, A History of Thought on Economic Integration (London: Macmillan, 1977), 14.

71 Machlup, A History, 16.

72 Machlup reported on Röpke's exploration of the meaning of the Latin word integratio, which he linked to the 'restoration of something lost' rather than to the creation of something new. Therefore, Röpke conceived of European integration as the reconfiguration of the pre-1929 economic order (i.e. the gold standard rule). According to the Geneva neoliberal school, 'integration' embodied a 'negative' meaning, that is, it implied first and foremost the removal of barriers and trade obstacles between states or territories, rather than the 'positive' merging of market sectors through potentially discriminatory agreements. See Slobodian, Globalists, 186-7 and 272.

73 Herber Gierch, Eurosclerosis', Kieler Diskussionsbeiträge, n. 112, Institut für Weltwirtschaft, Kiel, 1985. Paper delivered at the regional meeting of the MPS in Sydney, 20 August.

74 Giersch, 'Eurosclerosis'.

75 The Maastricht Treaty envisaged a 'Social Policy Protocol' which, however, did not envisage any concrete adoption of the measures promoted by the supporters of the 1970s-early 1980s' 'Social Europe' agenda, such as the reduction of working hours with equal salary or the participation of workers in the control of multinationals. It was signed by only eleven of the twelve EU member countries, excluding the United Kingdom. Notwithstanding the protocol's implementation, the kernel of labour legislation remained under member states' control. See Gerda Falkner, 'The Maastricht Protocol on Social Policy: Theory and Practice', Journal of European Social Policy, 6, 1 (1996), 1-16.
} 
banks, as well as a rise in taxes for capital holders and businessmen. ${ }^{76}$ Unsurprisingly, the neoliberal movement reacted with a mixture of distrust and utter rejection.

During the 1982 MPS meeting, the economist Robert Lozada-Heller scrutinised the 'side effects' of Mitterrand's economic strategies on the EEC. ${ }^{77}$ In his opinion, this economic policy put Paris's compliance with the EMS monetary requirements under intense pressure. Notwithstanding, he stressed the extent to which Mitterrand's programmes and the main pillars of the EEC's 'dirigiste' architecture were convergent. In addition, Lozada-Heller also recalled how prominent French liberal intellectuals - such as Daniel Villey and Jacques Rueff, both of whom were members of the early French group within the MPS ${ }^{78}$ - had always considered the EEC as an institutional engine able to reconcile socialist and liberal forces in France after the Second World War. ${ }^{79}$ However, while for the liberals the EEC should have just paved the way to the lowering of trade barriers, tariffs and the opening up of national markets to global competition, for the socialists it became a sort of 'organized "community", aimed at defining a policy of planned economic and social development for a new political entity called Europe'. ${ }^{80}$ But what stands out in Lozada-Heller's analysis is his scaling down of the ideological rift that would characterise France's commitment to European economic and monetary integration, both under Giscard D'Estaing (1974-81) and then under Mitterrand. In fact, the author argued that the EMS was one of the

rare legacies from Giscard D'Estaing that the socialists have not complained about. And why should they since it is a bureaucratic institution in charge of the operation of a price (in that case exchange rate) fixing scheme, i.e. the very idea the socialists have of proper economic procedure? The ironic aspect of this . . . is that. . . it may well be that the EMS, accepted without qualms by the socialists, will turn out to be one of the most bothersome legacies, politically speaking, that they got from their predecessors. ${ }^{81}$

As early as 1982, Lozada-Heller grasped the conundrum that would trigger European leftist parties' anguish in dealing with European integration and the whole process of globalisation. The so-called Keynesian settlement was no longer proving to be fully manageable, even by leftist forces, ${ }^{82}$ due to the pressure on European currencies caused by the combination of the second oil shock and the deflationist monetary policies pursued by the Federal Reserve since $1979 .{ }^{83}$ From 1983 onwards, French socialists would somehow brush up previous programmes of 'authoritarian liberalism' (such as Raymond Barre's deflationist programmes) ${ }^{84}$ and start to support restrictive monetary, fiscal and budgetary policies that deeply undermined their traditional reliance on social-oriented policy goals

76 Warlouzet, Governing Europe, 149-53; Gilbert, Surpassing, 157.

77 Robert Lozada-Heller, 'The Case of France', MF, box 112, HILA. Hereafter: Lozada-Heller, 'The Case'. There is little information on him. Certainly, Lozada-Heller collaborated with the journal Ordo in the early 1980s and was close to Milton Friedman and his wife, Rose. See Frank Banker, Agnes Labrousse and Jean-Daniel Weisz, 'The Evolution of Ordoliberalism in the Light of the Ordo Yearbook: A Bibliometric Analysis', in Agnes Labrousse and Jean-Daniel Weisz, eds., Institutional Economics in France and Germany: German Ordoliberalism versus the French Regulation School (Berlin: Springer, 2001), 174; Milton Friedman and Rose Friedman, Two Lucky People: Memoirs (Chicago: The University of Chicago Press, 1998), 535.

78 François Denord, 'French Neoliberalism and Its Divisions: From the Colloque Walter Lippmann to the Fifth Republic', in Mirowski and Plewhe, The Road, 45-67.

79 Lozada-Heller, 'The Case'.

80 Ibid.

81 Ibid.

82 Stephanie L. Mudge, 'What's Left of Leftism? Neoliberal Policies in Western Party Systems, 1945-2000', Social Science History, 35, 3 (2011), 337-80.

83 Herman Schwartz, 'Global Imbalances and the International Monetary System', in Thomas Oatley and W. Kindred Winecoff, eds., Handbook of the International Political Economy of Monetary Relations (Cheltenham: Edward Elgar, 2014), 69-88.

84 Bliek and Parguez, 'Mitterand's Turn', 99-100. 
and welfare state provisions. According to Lozada-Heller, French socialists embodied the broader political impasse that would then catch the European left as a whole, ${ }^{85}$ as they progressively 'shift[ed] [their] priority from a purchasing power distribution policy to a price-wage freeze policy, to try to reduce the inflation rate in France to a level more in line with one prevailing in the other EEC countries' ${ }^{86}$

At that time, the author believed that the main challenges for neoliberals were twofold: first, they should evaluate the impact that the participation in the ever tightening EEC monetary rules would have on French socialists' strategies; second, neoliberals should look at the effects that Mitterrand's France would generate on the EEC as something in direct relation with the degree of damage that their policy will inflict on the competitiveness of the French economy'. ${ }^{87}$ But neoliberals could take advantage of this: the economic and political turbulence that the hyper-regulative French economic policy would create in the whole community's economic performances would, in turn, bring to the fore the need for a further spread and implementation of liberal-oriented ideas, so that in the near future the opponents of Mitterrand's France should quite paradoxically shout 'Vive les socialistes'. ${ }^{88}$ In many respects, Lozada-Heller's prediction was all but an extravagant joke.

\section{'Evolutionary Competition' versus 'Constructivist Designs': Laying the Groundwork for Post-1992 Europe}

MPS neoliberals' interest in European integration was reinforced in light of the fall of the Berlin Wall and the negotiations on the 'Europe 1992 initiative'. ${ }^{89}$ The fil rouge that bound together the contributions delivered during the 1990 MPS meeting in Berlin, titled 'Europe in an Open World Order', lay in the effort to conceptualise the main policy trends that the EEC/EU would experience in light of the seeming demise of the 'communist threat' on the continent. In so doing, the speakers (Gerard Radnitzky, Jagdish Bhagwati, Jürgen von Hagen, Michele Fratianni, Karl-Heinz Paqué and James Buchanan $)^{90}$ debated the opportunities that the end of Cold War Europe seemed to open for the strengthening of neoliberalism within manifold fields: the downsizing of the EEC social tasks, its trade and monetary policies, as well as its constitutional and federalist shape.

The Austro-Swedish Gerard Radnitzky - who turned his interests from aeronautical engineering to political philosophy after reading Hayek's Road to Serfdom ${ }^{91}$ - reflected on the clash between 'evolutionary competition' and 'constructivist designs' (given that philosophical constructivism was the inspirational source of socialism, according to Hayek) as the driving forces of post-1992 Europe's institutional architecture. ${ }^{92}$ Quite interestingly, Radnitzky included both Soviet style socialism and the German social market economy amongst the intellectual legacies that post-1992 Europe should rid itself of. Although the social market economy's roots aligned in the instances of the German

\footnotetext{
85 Stephanie L. Mudge, Leftism Reinvented: Western Parties from Socialism to Neoliberalism (Cambridge, MA: Harvard University Press, 2018).

86 Lozada-Heller, 'The Case'.

87 Ibid.

88 Ibid. Milton Friedman, too, attributed a non-negligible part of Thatcher's re-election as the UK's prime minister to the measures already promoted by Mitterrand in France, thus considering the ensuing French U-turn as one of the main reasons for the 'intellectual bankruptcy' of both French and, by extension, European socialists. See Milton Friedman, 'Mitterrand Elects Thatcher', Newsweek, 4 July 1984, 51.

89 The Article 13 of the Single European Act established that, by 31 December 1992, the EEC would set up the Single Market, which was defined as 'an area without internal frontiers in which the free movement of goods, persons and capital is ensured'. Gilbert, Surpassing, 175.

90 The 1990 MPS conference also hosted contributions by Victoria Curzon Price, Alan A. Walters, John Burton, R.M. Hartwell and Hans Willgerodt.

91 Hardy Bouillon, 'Gerard Radnitzky: From Philosophy of Science to Political Philosophy. A Tribute by Hardy Bouillon', Journal for General Philosophy of Science/Zeitschrift für allgemeine Wissenschaftstheorie, 38, 2 (2007), 205-18.

92 Gerard Radnitzky, 'European Integration: Evolutionary Competition against Constructivist Design', Mont Pèlerin Society papers [hereafter: MPS], box 28, HILA. Hereafter: Radnitzky, 'European Integration'.
} 
ordoliberal school, Radnitzky endorsed Hayek's criticisms against the advocates of this theory, since they would try 'to use the market in the service of what is called "social justice". ${ }^{93}$ In this respect, Radnitzky failed to recognise to what extent the attribute 'social' was mainly conceived as a sort of 'tactically necessary concession to the strength of organized labor and socialist sentiment in postwar Germany [rather] than as an indicator of a core aspect of [social market economy's] philosophy'. ${ }^{94}$ By equalising social policy goals and socialism per se, Radnitzky quite naively maintained that only the limitation of Brussels's social tasks and the abandoning of Delors's principle of 'territorial cohesion'95 - which included financial support to deprived or de-industrialised European areas - could guarantee the success of a Hayekian-oriented 'evolutionary competition' over allegedly social-oriented 'constructivist designs' in the establishment of post-Cold War Europe. ${ }^{96}$

As for the EEC trade policies, they were discussed by the well-known Indian-American economist Jagdish Bhagwati, who reflected on the global implications of the post-1992 European economic approach towards free trade under the GATT rules. ${ }^{97}$ Because the GATT Uruguay round (1986-94) was still ongoing ${ }^{98}$ when he delivered this speech, Bhagwati analysed the extent to which economic regionalism could damage the flourishing of a new global trade order after the dissolution of the socialist camp. He did so by going back to Article 29 of the GATT statute, which 'sanction[ed] free trade areas and customs unions (which have also common external tariffs)' but at the same time warned against regional blocs being provided with preferential tariffs and discriminatory trade norms to the disadvantage of external countries or competing regional areas. ${ }^{99}$ By reframing the debates amongst neoliberal thinkers after the Second World War on the best-suited institutional framework that international markets should have taken after the war's outcome, ${ }^{100}$ Bhagwati wondered how the new architects of the post-1989 global order would deal with the issue of economic regionalism embodied not only by the EEC/EU but also by the United States or Canada, who considered the ' 1992 initiative' a sort of economic threat that had to be rebalanced by a 'countervailing bloc', such as the US-Canada Free Trade Agreement (FTA).

According to Bhagwati, the way to cope with this challenge was to reinforce the binding nature of GATT resolutions, as well as the need for all the newly established regional trade agreements which aimed to join the GATT to decrease their external tariffs to all other GATT members. ${ }^{101}$ This was considered the key issue to prevent the resurgence of economic nationalism and clashes between the strongest national economies (e.g. the United States), regional blocs (e.g. the EEC, NAFTA) and poor countries in the post-1989 global order. ${ }^{102}$ Within this framework, even a regional bloc such as the EEC could coexist with a further consolidated post-1989 liberal-oriented global order. As the negotiations for the Uruguay Round were demonstrating at the time, the EEC and its largest member countries, such as France and West Germany, were supportive of a global process of liberalisation, which nonetheless had to be ruled within a set of binding regulations designed to manage the further opening up of international markets. At that time both Delors and his collaborator, Pascal Lamy, used catchwords like 'managed' or 'organised liberalisation' to describe this process. The EEC's regional shape indeed found common ground with the GATT's global reach in Lamy's statement: 'if you liberalize, you must organize'. ${ }^{103}$

\footnotetext{
93 Radnitzky, 'European Integration'.

94 Slobodian, Globalists, 266 and 358, n. 15.

95 Radnitzky, 'European Integration'.

96 Mark Gilbert, Cold War Europe: The Politics of a Contested Continent (London: Rowman \& Littlefield, 2016).

97 Jagdish Bhagwati, 'Regional Bloc vs Multilateralism in the World Economy', MPS, box 28, HILA. Hereafter: Bhagwati, 'Regional Bloc'.

98 Lucia Coppolaro, 'Globalizing GATT. The European Union and the Trade Regime in the 1980s-1990s', Journal of European Integration History, 24, 2 (2018), 335-52.

99 Bhagwati, 'Regional Bloc'.

100 Slobodian, Globalists, 182-93.

101 Bhagwati, 'Regional Bloc'.

102 See Jagdish Bhagwati, In Defense of Globalization (Oxford: Oxford University Press, 2004).

103 Coppolaro, 'Globalizing GATT', 341; Rawi Abdelal and Sophie Meunier, 'Managed Globalization: Doctrine, Practice and Promise', Journal of European Public Policy, 17, 3 (2010), 350-367.
} 
Together with the intertwining transformations of both the EEC and the GATT around 1989-90, the road towards European Monetary Union (EMU) was perceived as one of the most important sources of analysis by participants in the MPS conference, such as the Italian Michele Fratianni and the German Jürgen von Hagen. ${ }^{104}$ Fratianni had spent most of his academic career in the US-based Ohio State University and Indiana University. He also served as economic advisor for the EEC between 1976-9, for the Reagan administration in the Council of Economic Advisers during 1981-2, as well as for the Organisation for Economic Cooperation and Development (OECD). Von Hagen, in turn, had obtained his $\mathrm{PhD}$ in economics in Bonn and then taught at Indiana University from 1987-92, where he probably met and collaborated with Fratianni. As experts in European monetary policy, they both started from recalling how the Treaty of Rome in 1957 had not explicitly endorsed the creation of a monetary union, let alone a single European currency, although some of the treaty's articles were consistent with the objective of a common monetary area. However, after the collapse of the Bretton Woods system and the global recession of the mid-1970s, the EEC authorities - e.g. through Jenkins and his famous 1977 Florentine speech ${ }^{105}$ - progressively perceived monetary policies as the 'driving political force to reach economic integration'. ${ }^{106}$ Also, Fratianni and von Hagen noticed how the Delors Report on monetary union in 1988 had been silent on a crucial aspect of 1970s and early 1980s global monetary policy - that is, inflation - which they analysed in close connection with another important element of economic investigation: the independence of central banks. ${ }^{107}$ Their basic intention was to understand the extent to which the establishment of a monetary union - with both a single currency and a single central bank - might be considered as a positive outcome of European integration, given the belief among several neoliberal-oriented thinkers ${ }^{108}$ that a monetary union could potentially undermine the basic engine of good monetary strategies, embodied by the principle of competition between monetary policies and central banks. ${ }^{109}$

Fratianni and von Hagen perceived what was commonly described as monetary cooperation among central banks as a potential form of 'monetary collusion', especially if European authorities did not impose an institutional separation between central banks and national policy makers. In so doing, they openly advocated the insulation of the new central bank from politicians' short-term and electoral interests. In addition, should the new monetary union's rules neutralise the effects of the monetary policy's competition within the European area, the new central bank would need to adopt the yardstick of a Bundesbank-shaped stance as far as inflation control, price stability and containment of debt rates of the EMU member countries were concerned. The creation of the EMU was thus seen as a desirable achievement of European integration inasmuch as high inflation rate countries - such as Italy - would benefit from the 'market discipline' ${ }^{110}$ embodied by German parameters. While the balanced redesigning of the European tax system was encouraged, the authors rejected the hypothesis of creating proper fiscal centralisation and coordination, since this would hamper both the independence and efficacy of the monetary policy itself. Therefore, the undertaking of a deflationist-oriented monetary policy, anchored on the pillars of the (national) balanced budget, ECB independence and the refusal of a centralised European fiscal policy, put Fratianni and von Hagen in perfect line with the aims of those European policy makers that would finally give birth to the EU monetary architecture. More than the mere triumph of some sort of 'free market fundamentalism', Fratianni and von Hagen's sketching out of the forthcoming EMU marked the growing emphasis on the disciplinary function of post-1989 European and economic monetary rules: if coordination between member states and European

\footnotetext{
104 Michele Fratianni and Jürgen von Hagen, 'European Monetary Union and Central Bank Independence', MPS, box 28, HILA. Hereafter: Fratianni and von Hagen, 'European Monetary'.

105 Ludlow, Roy Jenkins, 126-30.

106 Fratianni and von Hagen, 'European Monetary'.

107 Gianni Toniolo, ed., Central Banks' Independence in Historical Perspective (Berlin: De Gruyter, 1988).

108 Friedrich von Hayek, The Denationalisation of Money: An Analysis of the Theory and Practice of Concurrent Currencies (London: IEA), 1976.

109 Fratianni and von Hagen, 'European Monetary'.

110 Ibid.
} 
authorities had to be pursued, this must be addressed towards the achievement of depoliticised macroeconomic goals (e.g. with regard to inflation and public debt). All in all, monetary policy had to be insulated from politics and, ultimately, from democratic and social claims, regardless of whether they come from national arenas or European institutions, such as the European Parliament. In this respect, Fratianni and von Hagen's views seemed to be closer to some sort of 'market constructivism' than to the mere unbridling of 'evolutionary competition' forces, as previously outlined by Gerard Radnitzky.

It was precisely around the rejection of the EEC and EU's social dimension that other participants in the MPS conference intervened during the 1990 Munich conference. The economist Karl Heinze Paqué, who between 2002 and 2006 would be Minister of Finance in the Sachsen-Anhalt region under the flags of the Free Democratic Party (Freie Demokratische Partei), advocated the reorganisation of European social provisions and resource allocation in accordance with the principle of welfare competition. Namely, national welfare systems must be conceived as simple 'determinants of a country's competitive position as a supplier of goods and services'. ${ }^{111}$ Paqué went so far as to ask himself whether European economic integration still needed a proper social dimension based on the EEC structural funds, the pursuing of work safety through the so-called European social dialogue. Paqué was inclined not to dramatise - as neoliberals tended to do - the general expenses linked to EEC welfare provisions, which 'looked bearable, ${ }^{112}$ but this was only because he acknowledged how the European social dimension still showed (and, in his opinion, should continue to show) its immature shape'.

Symptomatically, Paqué seemed to overturn the very rationale of Delors's designs for post-1992 European social policy, whose conceptual pillar - that is, the further harmonisation of national social legislations - was interlaced with that of building up an ever more integrated and competitive EU capitalist economy at the global level. In Delors's opinion, additional social cohesion should be conceived of as a way to deal with three main challenges: (a) to reduce the 'structural drawback of economic divergence between the rich core of Europe and its poorer fringes'; ${ }^{113}$ (b) to modernise the agricultural sector, which also implied a reform of the Common Agricultural Policy (CAP); (c) to deepen European solidarity so as to cope with the long-lasting burden of post-1970s' massive unemployment. Beyond Delors's somewhat rhetorical call to be 'faithful to our [European] personality', ${ }^{114}$ the goal of improving social solidarity as a means to pursue non-inflationary economic growth within the wider framework of global competition really nourished Delors's commitment - and, in many respects, his own political conundrum - to the relaunching of European integration at that time. This demonstrates the degree of political discord between the Delors Commission and the neoliberal intellectuals gathered in Munich in 1990. Both the 'factions' apparently aimed at achieving the same far-reaching goal to boost European growth within a competitive and market-oriented institutional framework - but the ultimate means through which this should be reached were clearly divergent. While Delors conceived of the community as an engine of sustainable economic growth, insofar as it worked as an 'area of solidarity, ${ }^{115}$ Paqué maintained that both historical experience and empirical studies demonstrated that 'integration does not have much to do with an international harmonization of labour laws and the building up of a supranational welfare system'. ${ }^{116}$ Paqué openly believed that the importance of social provisions would be progressively substituted by the likely increase in European GDP performances, which would finally make the demand for any form of the welfare state fade into the background. In a sense, the dismissal of socialism in Eastern Europe would even reinforce Western and

\footnotetext{
111 Karl-Heinz Paqué, 'Does Europe’s Common Market Need a "Social Dimension"?', MPS, box 28, HILA. Hereafter: Paqué, 'Does Europe'.

112 Paqué, 'Does Europe'.

113 Alessandra Bitumi, 'Narrating Social Europe: The Search for Progress in the "Age of Delors", Jacques Delors Institute, policy paper n. 185, 2017, 13 .

114 Bitumi, 'Narrating', 12.

115 Bitumi, 'An Uplifting', 208.

116 Paqué, 'Does Europe'.
} 
Eastern Europeans' detachment from the call for public funding of robust welfare state programmes, and in parallel it would boost their call for greater 'freedom' in European post-1989 political systems.

The perception of an unexpected 'happy coincidence' in European history that would further spread the very seeds of liberalism was the starting point of James M. Buchanan's reflections on the 1990 MPS meeting. ${ }^{117}$ The well-known American economist emphatically compared the conditions of post-1989 Europe to those of the United States in 1787, stressing the need for Europe to build on James Madison's most important aspects of his 'grand design for American federalism... that of limiting the range and scope of political authority over the liberties of citizens. ${ }^{118}$ According to Buchanan, this was true because, as in 1787 North America, 1990 European 'citizens of the separated nation states face[d] an opportunity to enter into a federal union that can be an instrument for achieving the enormous gains of economic integration'. ${ }^{119}$ This federal union should be based on a constitutional chart which would include the ultimate 'right to secede'; otherwise, both its legitimacy and efficacy could never come into being. At the same time, secession would never be a significant alternative if the full centralisation of political authority was formally prohibited. In a sense, Buchanan's optimism stemmed from how the fall of the Berlin Wall and the 'pacific revolutions' that the Central and Eastern European countries were experiencing at that time actually unfolded. Moreover, Buchanan spread his views in a period of growing dissatisfaction with nationalism and the apparent 'eclipse of the nation in an era of globalization', ${ }^{120}$ although what he was mostly worried about was the survival of the so-called 'state Leviathan' (namely, the conceptual primacy of sovereign nation-states) even in a post-1989 global order. However, 'the particular convergence of ideas and events at the end of the [twentieth] century ${ }^{\prime 21}$ - from the fall of the Berlin Wall to the seeming demise of the Soviet 'Leviathan' - nourished Buchanan's optimism as far as the appearance of a 'European Madison' and the federalist evolution of the EEC were concerned.

It is worth recalling how in those years another strand of European neoliberals, such as those gathered in the UK-led neoliberal think tank, the Bruges Group, ${ }^{122}$ fought for a sharply different political evolution to that of the forthcoming EU, in accordance with Thatcher's claim about the need to conceive of Europe as a 'family of nations' provided with full sovereignty ${ }^{123}$ rather than a 'constitutionalised' supranational body. The clash between those who advocated the 'rescue of the nation state' ${ }^{\text {'24 }}$ as the best suited 'locus of sovereignty' and those who 'saw the very merit of European institutions in [their] ability to pickpocket national sovereignty for the sake of locked-in market reforms at the supranational level ${ }^{125}$ was stark and turned into a larger debate concerning neoliberals' commitment to the designing of post-Cold War Europe. As for Buchanan, the specific 'rule of law' that would inform the European constitution was unmistakably conceptualised as a means to encapsulate within a liberaloriented constitutional framework the range of political actions that European institutions could pursue in the developing post-Cold War order. Nevertheless, the events that would mark the following years - from the EU inclusion of Eastern European countries, beginning in 2004, to the failure of the European constitutional project in 2005 - proved both how true and how naïve Buchanan's optimism was in the 1990 Munich meeting.

\footnotetext{
117 James Buchanan, 'An American Perspective on Europe's Constitutional Opportunity', MPS, box 28, HILA. Hereafter: Buchanan, 'An American'.

118 Buchanan, 'An American'.

119 Ibid.

120 Slobodian and Plehwe, 'Neoliberals', 96.

121 Buchanan, 'An American'.

122 It was created in 1989 by prominent affiliates (e.g. Lord Harris) of one of the most recognised UK-based neoliberal think tanks, the Institute of Economic Affairs. The name 'Bruges Group' was borrowed from the seminal speech delivered by Margaret Thatcher in Bruges in 1988.

123 See Étienne Balibar, 'Absolute Capitalism', in Callison and Manfredi, Mutant, 272-5.

124 Alan Milward (with George Brennan and Federico Romero), The European Rescue of the Nation State (London: Routledge, 1992).

125 Slobodian and Plehwe, 'Neoliberals', 95.
} 


\section{Conclusion}

In reflecting on the emergence of European neoliberal thought in the interwar period, ${ }^{126}$ Tony Judt commented on Hayek's Road to Serfdom and singled out the 'two animosities' that stood out as the main intellectual patterns in that book. According to Judt, these 'animosities' corresponded to Hayek's 'dislike for the overconfident social democratic urban planning of early 1920s Vienna, and distaste for the Christian Social corporatist models that replaced them on the national level following the reactionary coup of $1934 .{ }^{127}$ Hayek firmly criticised 1920s-30s Austrian socialists and Christian Democrats as both responsible, even if in different ways, for 'Austria's collapse into the arms of Nazi authoritarianism by 1938'. Judt then concluded:

Hayek is quite explicit on this count: if you begin with welfare policies of any sort ... you will end up with Hitler. Not merely with social democratic housing projects or right-wing subsides for 'honest' winegrowers, but Hitler. Thus, rather than run such a risk, democracies should avoid all forms of intervention which distort the properly apolitical mechanism of a market economy. ${ }^{128}$

Even though no such thing as Nazism seemed to loom over 1980s' Europe, Hayek's statements seemed to have been disseminated and reinforced by MPS-linked intellectuals, who aimed at dispossessing European political and economic institutions of their main social implications, that is, the conflictual and often unpredictable outcomes of political struggles over the distribution of resources, wealth and power.

As for Western Europe, the demise of the Iron Curtain and the negotiations for the Maastricht Treaty did not entail either the undisputed triumph of market-oriented policy measures or the complete overcoming of what seemed to be at the heart of MPS intellectuals' concerns after 1989, to wit, the perpetuation of regulative authorities with social or political aims over market functions. As noted by Antonio Martino, who became the MPS president in $1988-90,{ }^{129}$ the issue at stake for neoliberals after 1989 was the following: 'will the change from totalitarian rule to electoral democracy widen the range of free choices open to individuals in their everyday lives, or will it just be a cosmetic change which will leave nearly everything else unchanged?'. ${ }^{130}$

By tackling the very rationale of Martino's thoughts, this article has highlighted how complex, contradictory and intellectually challenging it was for the participants in the MPS conferences to deal with an explicitly pro-market regional body - the EEC - that at the same time encapsulated what they perceived as the worst shortcomings of state-led or even socialist economies: from strict regulatory policies in the fields of social policy to the distortive effects on international trade. As shown, MPS neoliberals undertook their scrutiny of the EEC policies within a threefold scheme: first, the socially-oriented initiatives adopted by Western Europe to tame the effects of the 1970s-early 1980s' process of globalisation; second, the EEC's participation in the global liberalisation of trade during the 1980s; third, the effects that the outcomes of bipolar confrontation could have on the reorganisation of Western Europe in parallel with the decay of Soviet socialism.

The 1982 and 1990 MPS conferences revealed how divergent were the MPS affiliates' interpretations of the whole 'European construction'. While some praised the EEC's (potential) contribution to global trade (Bhagwati), to the reshuffling of the international monetary system (Fratianni and von Hagen) and to the opening up of unprecedented European constitutional opportunities after

\footnotetext{
126 Hagen Schulz-Forberg, 'Embedded Early Neoliberalism: Transnational Origins of the Agenda of Liberalism Reconsidered', in Plehwe, Slobodian and Mirowski, Nine Lives, 169-96.

127 Tony Judt with Timothy Snyder, Thinking the Twentieth Century (New York: Penguin, 2012), 344.

128 Judt, 'Thinking', 344.

129 Martino would be Minister of Foreign Affairs (1994-5) and Minister of Defence (2001-6) respectively in the first and second of Silvio Berlusconi's cabinets.

130 Antonio Martino, 'Liberalism in the Coming Decade. The Role of the Mont Pèlerin Society', MPS, box 28, HILA.
} 
1989 (Buchanan), others (Friedman, Curzon Price, Paqué, Radnitzky) underscored the distortive effects that European sectorial integration and regulative policies could stimulate across the international capitalist system. Such interpretative discrepancies made evident three elements: first, the extent to which the neoliberal thought collective was, as said, intrinsically fragmented; second, how the relationship between neoliberalism and European integration was (and still is) 'subject to ... constant bifurcation and recombination', ${ }^{131}$ thus revealing the need to interpret neoliberalism in the light of its permanent adaptability to changing historical contexts; third, that these conflicting views are retrospectively telling of two interlaced and broader issues, namely, the reason why 'militant neoliberals' had a moderate impact on the actual remaking of the EEC and EU policy rules between the late 1980s and the early 1990s, as well as the fact that at that time they were 'more often [...] the EU's critics than its champions.' ${ }^{132}$

While several aspects of both the Single European Act (i.e. the free circulation of capital, goods, services and people envisaged by the single market) and the looming disintegration of Soviet socialism were perceived by neoliberal intellectuals as an opportunity both to get rid of the European 'dirigiste' tradition and to enhance the further 'marketisation' of the EU's economic policies, the Maastricht Treaty did not dismantle either the principle of intergovernmentalism as the linchpin of the EU decision-making process or the goal of centralising its monetary policy through the EMU and the forthcoming ECB - nor, finally, the ambition to carry on its (quite limited indeed) social commitment (i.e. the EU Social Protocol). Notwithstanding, neoliberals' main goal remained that of depriving the institutional engines of twentieth-century European capitalism - namely, the EEC and the EU - of extra economic scopes, which included those social and political aims that often neglect the primacy of competition and price stability as the best tools through which to shape and rule modern societies. In so doing, more than the outcome of a deliberate 'neoliberal project', the 1980s and the early 1990s' European integration process turned out to be a trigger for further fragmentation within the transnational neoliberal community as a whole.

Acknowledgements. This work is supported by the University of Padova under the 2019 STARS Grants programme DWNS - Dealing with the Neoliberal Storm: Italy, the Global Monetarist Shift, and the European Integration Process (1979-92). I wish to thank Prof. Emmanuel Mourlon-Druol, Alec Fiorini and the three anonymous referees for their insightful comments and suggestions throughout the drafting process of this contribution. All remaining errors are my own.

131 Slobodian and Plehwe, 'Neoliberals', 105.

132 Ibid., 90.

Cite this article: Ventresca R (2022). Neoliberal Thinkers and European Integration in the 1980s and the Early 1990s. Contemporary European History 31, 31-47. https://doi.org/10.1017/S0960777321000199 